\title{
DE-A109-00SR22188 JOURNAL ARTICLE 2008 08-10-P Evaluating Hydroperiod Response in Restored Carolina Bay Wetlands Using Soil Physicochemical Properties
}

\author{
Christopher D. Barton, ${ }^{1,2}$ Danielle M. Andrews, ${ }^{1}$ and Randall K. Kolka ${ }^{3}$
}

\begin{abstract}
Carolina bays are shallow depression wetlands found in the southeastern United States that have been severely altered by human activity. The need to restore these complex and diverse systems is well established, but our limited understanding of wetland hydrologic processes in these systems hinders our ability to assess the effectiveness of bay restoration efforts. Carolina bays exhibit a wide range of moisture regimes from seasonally saturated to semipermanently inundated. Differing physicochemical properties of soils within bay interiors may control bay hydrology. However, previous efforts to establish relationships between soil characteristics and bay hydrology have been inconclusive. An assessment of soil and hydroperiod was initiated in 16 bays designated to be restored and 6 bays that were not restored (reference). Soil morphology was described, and permanent monitoring wells were
\end{abstract}

installed at each site. Multiple regression analysis was used to determine relationships between the soil physicochemical characteristics and the bay hydroperiod for restored and reference bays in both pre- and postrestoration periods. A significant relationship $\left(r^{2}=0.75, p=0.02\right)$ between prerestoration hydroperiod and clay content in the argillic horizon (Bt) of the reference bays was observed. This relationship was then used to evaluate hydroperiod change in the restored bays from the postrestoration period. The relationship accurately identified sites that exhibited high prerestoration hydroperiods and did not need hydrologic restoration $(n=4)$ and effectively showed sites that exhibited substantial increases in hydroperiod due to the restoration activities $(n=7)$.

Key words: argillic soil horizon, Carolina bay, restoration, wetland hydroperiod, wetland soils.

\section{Introduction}

Carolina bays are shallow, elliptical depression wetlands found in the Atlantic coastal plain of the southeastern United States and range in size from 3,600 ha to less than a hectare (Sharitz 2003). These wetlands exhibit a range of moisture regimes from seasonally saturated to semipermanently inundated (Schalles \& Shure 1989) and are of ecological significance as habitat for several wildlife communities and rare species (Sharitz \& Gibbons 1982; Mahoney et al. 1990; Semlitsch et al. 1996; Krajick 1997). Many Carolina bays and similar depression wetlands within the region have been severely disturbed, primarily for agricultural purposes. In South Carolina, one study examined over 2,500 Carolina bays and found that 97\% exhibited some form of alteration (Bennett \& Nelson 1991). The degree of disturbance ranged from a single drainage ditch to complete wetland loss from filling activities associated with development. Given that the future of

\footnotetext{
${ }^{1}$ Department of Forestry, University of Kentucky, 203 Thomas Poe Cooper Building, Lexington, KY 40546-0073, U.S.A.

${ }^{2}$ Address correspondence to C. D. Barton, email barton@uky.edu

${ }^{3}$ North Central Research Station, USDA Forest Service, 1831 Highway 169 E.,

Grand Rapids, MN 55744, U.S.A.
}

isolated depression wetland protection in the United States under section 404 of the Clean Water Act is currently at issue (Petrie et al. 2001; Downing et al. 2003; Sharitz 2003), conservation and restoration of these important habitats are of interest.

Research on biogeochemical and hydrologic processes in Carolina bays and similar isolated depression wetlands is limited. Previous studies have suggested that Carolina bays receive water inputs from meteoric, surface, and groundwater sources; however, evidence linking a specific water source to bay hydroperiod (duration of inundation) has not been clearly demonstrated (Sharitz 2003). Differing physical properties of soils within and surrounding bay interiors likely influence bay hydrology. In general, landscapes adjacent to Carolina bays and rims located on the wetland edge are characterized by sandy surface deposits. Because of the high permeability associated with sandy soils, overland flow or run-off into bays is uncommon. However, bay interior soils often contain elevated concentrations of clay and less permeable sediments that are conducive to the development of an aquiclude or clay lens. Once developed, vertical infiltration within the depression area decreases and ponding ensues. Although the aforementioned physical conditions have been observed in several Carolina bays (Lide et al. 1995; Reese \& Moorhead 1996), variability in soil properties within individual bays 
has resulted in a myriad of flooding and drying patterns that have not been fully characterized and are currently unexplained. As such, efforts to characterize Carolina bay hydrogeology because it is related to soil physicochemical properties are needed.

Determining whether a bay is suited for restoration generally involves an assessment of disturbance level (soils, hydrology, vegetation, and wildlife), location and accessibility, and aesthetics. Unfortunately, these activities require a great amount of time and resources. Considering that soil physicochemical properties likely contribute to the depth and duration of ponding in Carolina bays, they may provide valuable information both to determine if a site is suitable for restoration and to evaluate restoration success. Using data from undisturbed reference bays for assessing pre- and postrestoration hydrology is complicated because some reference bays remain ponded throughout the year, whereas others, within a similar landscape unit, are predominantly dry. Moreover, the ephemeral nature of many Carolina bays and their relationship with weather patterns would necessitate a long prerestoration assessment period to ensure that changes in hydroperiod are the result of the restoration effort and not climatic variability. Soil physical and morphological characteristics should provide clues about the history of saturation in both disturbed and reference Carolina bays. Understanding which specific properties contribute to hydroperiod could help guide restoration efforts. To address these needs, a project was initiated with the following objectives: (1) determine relationships between soil physicochemical properties and hydroperiod in Carolina bays located in the upper coastal plain of South Carolina and (2) assess the influence of soil on hydroperiod change in bays that were restored.

\section{Methods}

\section{Soils and Topography}

Twenty Carolina bays in the nonindustrialized management area of Savannah River Site (SRS), South Carolina, were identified as candidates for restoration in 1999 (Fig. 1). All 20 bays were less than 2 ha in size and possessed an active drainage ditch and nearly all had a vegetation composition characteristic of a disturbed wetland system. Of the 20 bays, 16 were randomly selected for restoration, and the remainder were planned to serve as unrestored references. Four additional bays of similar size with limited disturbance were also selected for use as reference sites. Two of the reference sites were monitored only for hydrologic variables and therefore were not included in this analysis. Preliminary studies were conducted in the 22 bays to characterize topography, landform area, soils, and history of disturbance. Bay elevations at $10 \times 10-\mathrm{m}$ resolution were determined through the use of standard surveying procedures and level circuitry equipment, and topography maps were produced. Presence of drainage ditches or scars was noted and surveyed. Sites containing drainage ditches
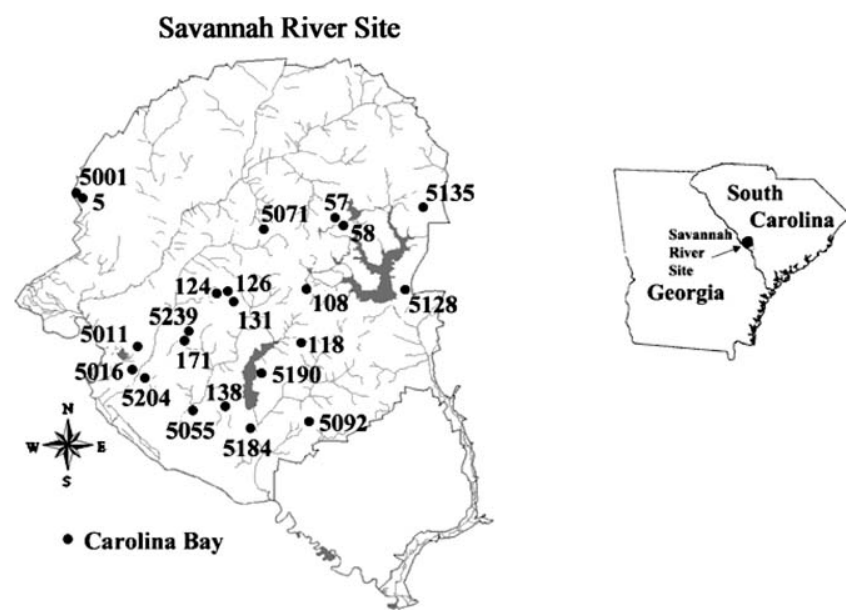

Figure 1. The SRS, South Carolina, U.S.A., and location of Carolina bay study sites.

were visited during wet periods to evaluate whether they were actively draining the bay. Vegetation sampling was also performed at each bay as another indicator of disturbance (De Steven et al. 2006).

Hydric soil boundaries were delineated at each site in 1999 using procedures outlined by the Corps of Engineers (Environmental Laboratory 1987; Federal Interagency Committee for Wetland Delineation 1989). Soil samples were collected in 1999 and 2000 at the topographic center of each bay. Soil cores were extracted by horizon to a depth of $2.0 \mathrm{~m}$, described, and subsampled. Subsamples from each horizon were analyzed for cation exchange capacity (CEC), total exchangeable bases (TEB) (soil macronutrients $[\mathrm{P}, \mathrm{K}$, $\mathrm{Ca}, \mathrm{Mg}$, and $\mathrm{Na}$ ] and micronutrients [ $\mathrm{Zn}, \mathrm{Mn}, \mathrm{Cu}$, and $\mathrm{B}])$, particle size, $\mathrm{pH}(1: 1)$, exchangeable acidity (EA), electrical conductivity (EC), and total nitrogen $(\mathrm{N})$ and carbon $(\mathrm{C})$. Extractable bases and $\mathrm{CEC}$ were analyzed using the $1 \mathrm{M}$ ammonium acetate $\left(\mathrm{NH}_{4} \mathrm{OAc}\right)$ at $\mathrm{pH} 7.0$ (Büchner funnel) by 5B1 and 5A1b methods, respectively (Natural Resources Conservation Service 1996). Phosphorus, zinc, manganese, copper, and boron were extracted using the Mehlich I procedure (Natural Resources Conservation Service 1996). Elemental concentrations were determined by inductively coupled plasma optical emission spectrometry (ICP-OES) analyses using a Perkin-Elmer Optima 4500 DV Optical Emission Spectrometer. Particle size analysis was performed using the pipette method (Natural Resources Conservation Service 1996). Soil pH and EC were measured in a 1:1 soil-water suspension and a 1:3 soil-solution suspension, respectively, with an HI 991301 Hanna $\mathrm{pH} / \mathrm{EC}$ meter and probe. Total $\mathrm{N}$ and $\mathrm{C}$ followed methods outlined in the Methods of Soil Analysis (Sparks et al. 1996).

\section{Hydrology}

Bay hydrology was monitored from January 2000 to January 2006 using a combination of staff gages, shallow monitoring wells, and semicontinuously recording data loggers. 
Each bay contained a well nest within the bay interior at the topographic center and at the wetland edge (hydric soil boundary or abrupt vegetation change). The well nests comprised a shallow monitoring well at a depth of $200 \mathrm{~cm}$ and four piezometers at 50,100, 200, and $300 \mathrm{~cm}$ depths. Shallow wells were constructed with 5.0-cm-diameter schedule 40 PVC pipe that was slotted along its entire length. Borings for the wells were drilled by hand using an $8.5-\mathrm{cm}$ bucket auger. Washed sand was packed from the base of the borings to approximately $25 \mathrm{~cm}$ above the screened area, and the remaining annulus was filled to just below the surface with slurry created from the bore cuttings. A plug of bentonite was placed at the surface to prevent leakage from above. Water level was measured bimonthly in the wells and piezometers using a Solinst 101 water level meter (Solinst Canada Ltd., Georgetown, Ontario, Canada). Surface water level was also semicontinuously monitored and logged at 6-hour intervals using WL-40 capacitance monitors (Remote Data Systems, Whiteville, NC, U.S.A.) and In-Situ pressure transducers (In-Situ, Inc., Fort Collins, CO, U.S.A.). Hydroperiod was calculated as the proportion of time that water was ponded in the bay, which was primarily determined by examining water table depths from the data loggers. In the event of a logging failure, hydroperiod was estimated from water table depth measurements that were manually taken from the shallow monitoring well. Open precipitation was measured at each site. Other meteorological variables and longterm data were provided by the SRS weather center.

\section{Bay Restoration}

Restoration of 16 Carolina bays with active drainage ditches began in 2001. Trees in the bay interiors were harvested to open the canopy and scarify soils (skidding logs) to stimulate germination of soil seed banks (De Steven et al. 2006). Drainage ditches were plugged at the discharge point (bay rim) with low-permeability clays. Several strategies for restoring the vegetation in replicated sets of these bays and their associated uplands were examined. Planned endpoints or treatments included pine- and hardwood-managed upland buffer zones and forested and herbaceous bay interiors. Additional information on the restoration strategy has been described elsewhere by Barton et al. (2004). The six remaining bays were not disturbed and used as unrestored references. Three of the six reference sites contained visible ditch scars (bays 108, 118, and 5055), but no drainage occurred during the study period, and it appeared that the drains had clogged or were no longer active. A disturbance history in the other three control bays $(57,58$, and 138$)$ has been documented (Barton et al. 2005), but no drainage ditches were found.

\section{Statistics}

SAS version 8 for Windows was used for statistical analysis (SAS Institute 1999). The $t$ tests with unequal variances were performed to determine significant differences between soil parameters among the restored and control bays. Significant differences were tested at $\alpha=0.05$. Stepwise multiple linear regression models were constructed to examine soil factors that were associated with variations in bay hydroperiod. A significance level of $p<0.15$ was required for retention in the models of individual parameters, and $p<0.05$ was considered significant for models.

\section{Results}

\section{Prerestoration Soil Characteristics}

Results from the soil and topographic surveys were compiled and are presented in Table 1 . The soil series listed in Table 1 represents the dominant soil type that was generally located in the central portion of the bay. Inclusions of other series were commonly associated with subtle changes in elevation as you move from the center to the edge of the bay. Inclusions were generally observed by the presence of nonhydric matrix colors in the upper $10 \mathrm{~cm}$ of the soil profile. All the bays were classified as fine to coarse-textured mineral soils, and none contained appreciable amounts of peat, which is similar to that described for other upper coastal plain bay soils (Newman \& Schalles 1990). The average size of the bays included in the study was $1.2 \mathrm{ha}$, with an average depth of $0.67 \mathrm{~m}$.

Statistical analyses indicated that soils in the restored and reference bays were not significantly different for all variables examined (Tables $2 \& 3$ ). Results from the surface horizon of the restored bays showed that the content of $\mathrm{Cu}$ and $\mathrm{Zn}$ ranged from 0.15 to $2.20 \mathrm{mg} / \mathrm{kg}$ and 0.20 to $2.30 \mathrm{mg} / \mathrm{kg}$, respectively (Table 2). Bays 126 and 171 exhibited the highest $\mathrm{Cu}$ concentrations $(2.20$ and $1.25 \mathrm{mg} /$ $\mathrm{kg}$ ), and bays 126 and 131 showed high $\mathrm{Zn}$ concentrations ( 2.30 and $2.05 \mathrm{mg} / \mathrm{kg}$ ). It should be noted that bay 126 is located adjacent to an industrial area at SRS, and thus, the higher concentrations of $\mathrm{Cu}$ and $\mathrm{Zn}$ may be attributed to run-off that entered this wetland system via a culvert prior to restoration. Solid waste (concrete rubble) that was removed prior to restoration may have also contributed to these findings in bay 126 . With the exception of one reference bay (118) that had a $\mathrm{Cu}$ concentration of $1.20 \mathrm{mg} / \mathrm{kg}$ and a $\mathrm{Zn}$ concentration of $6.60 \mathrm{mg} / \mathrm{kg}$, the other references had $\mathrm{Cu}$ and $\mathrm{Zn}$ concentrations within the given ranges for those of the restored bays.

The boron concentration of the bay soils ranged between 0.05 and $0.15 \mathrm{mg} / \mathrm{kg}$, with a similar average value between the restored and the reference bays (Table 2). Widely varying concentrations of $\mathrm{Mn}$ from below detection in bay 5055 to $212 \mathrm{mg} / \mathrm{kg}$ in bay 5184 were observed. Restored bays showed average $\mathrm{Mg}$ and $\mathrm{Na}$ concentrations of 13.41 and $10.44 \mathrm{mg} / \mathrm{kg}$, respectively. Except for reference bay 118 , which had a slightly higher concentration of $\mathrm{Mg}(28.50 \mathrm{mg} / \mathrm{kg})$, all other reference bays exhibited similar $\mathrm{Mg}$ and $\mathrm{Na}$ concentrations. The average concentration 
Table 1. Size and soil characteristics at the topographic center of study areas.

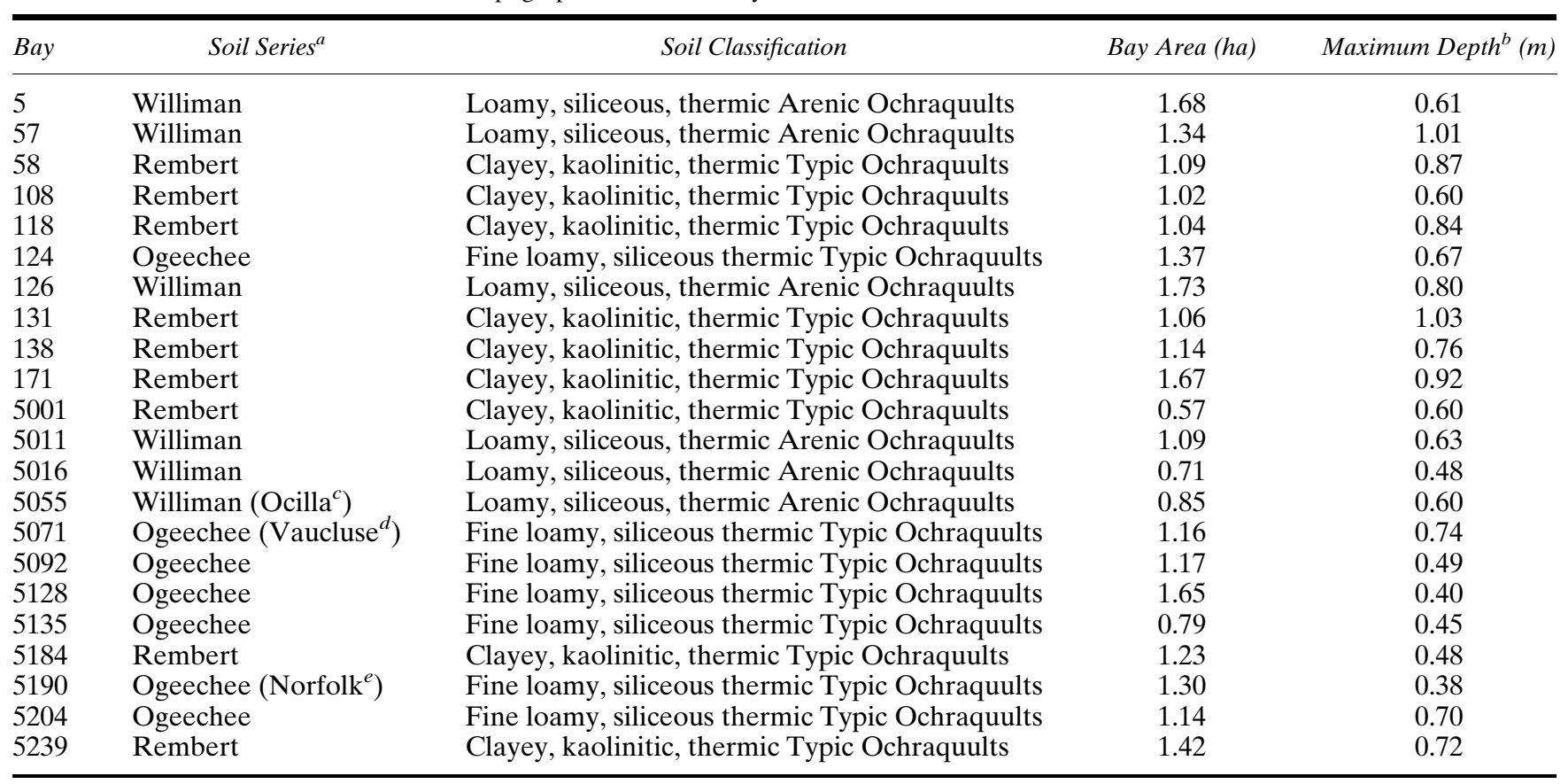

${ }^{a}$ As identified in the Soil Survey of Savannah River Plant Area (Rogers 1990).

${ }^{b}$ Topographic relief from the bay rim to the topographic center of the bay.

${ }^{c}$ Not hydric when sampled due to disturbance or possible inclusion of Ocilla soil (loamy, siliceous, thermic aquic Arenic Paleudults).

${ }^{d}$ Not hydric when sampled due to disturbance or possible inclusion of Vaucluse soil (fine loamy, siliceous, thermic Typic Hapludults).

${ }^{e}$ Not hydric when sampled due to disturbance or possible inclusion of Norfolk soil (fine loamy, siliceous, thermic Typic Paleudults).

of $\mathrm{P}$ was $11.7 \mathrm{mg} / \mathrm{kg}$ for the restored bays and $8.21 \mathrm{mg} / \mathrm{kg}$ for the reference bays. The $\mathrm{Ca}$ concentrations varied widely for all bays, with a low of 31.0 and a high of 367.5 $\mathrm{mg} / \mathrm{kg}$, but showed similar concentration means between the restored and the reference sites.

No notable differences were noted when comparing the restored and reference bays for $\mathrm{pH}, \mathrm{EC}$, and $\mathrm{CEC}$ (Table 3). For the TEB, reference bay 118 and restored bay 5092 had higher values (20 and 23 ) than all the other bays, which ranged generally from 4 to $14 \mathrm{cmol} / \mathrm{kg}$. All bays showed similar $\mathrm{C}$ and $\mathrm{N}$ concentrations.

\section{Hydrology}

Prerestoration hydrology of the bays revealed that most of the restored bays exhibited a very short hydroperiod (ponded $<10 \%$ of year), although some were ponded for a significant time such as bays 5 and 124 (Table 4). The

Table 2. Prerestoration elemental characteristics of surface soil horizon in restored and reference Carolina bays. ${ }^{a}$

\begin{tabular}{|c|c|c|c|c|c|c|c|c|c|}
\hline Treatment & $P(m g / k g)$ & $K(m g / k g)$ & $\mathrm{Ca}(\mathrm{mg} / \mathrm{kg})$ & $M g(m g / k g)$ & $Z n(m g / k g)$ & $M n(m g / k g)$ & $\mathrm{Cu}(\mathrm{mg} / \mathrm{kg})$ & $B(m g / k g)$ & $\mathrm{Na}(\mathrm{mg} / \mathrm{kg})$ \\
\hline \multicolumn{10}{|l|}{ Restored } \\
\hline$n$ & 16 & 16 & 16 & 16 & 16 & 16 & 16 & 16 & 16 \\
\hline Maximum & 19.0 & 31.0 & 367.5 & 22.0 & 2.3 & 212.5 & 2.2 & 0.15 & 14.5 \\
\hline Average & 8.2 & 13.2 & 86.2 & 13.4 & 0.8 & 41.5 & 0.6 & 0.12 & 10.4 \\
\hline $\mathrm{SD}$ & 5.2 & 7.2 & 78.6 & 4.7 & 0.6 & 58.5 & 0.5 & 0.03 & 2.3 \\
\hline Minimum & 5.0 & 7.0 & 36.0 & 8.0 & 0.5 & BDL & 0.1 & 0.10 & 4.5 \\
\hline Maximum & 30.5 & 30.0 & 282.5 & 28.5 & 6.6 & 87.0 & 1.2 & 0.15 & 12.0 \\
\hline Average & 11.7 & 16.0 & 97.2 & 13.5 & 1.8 & 23.6 & 0.7 & 0.11 & 9.6 \\
\hline $\mathrm{SD}$ & 10.6 & 9.5 & 104.2 & 8.5 & 2.7 & 36.1 & 0.5 & 0.02 & 3.1 \\
\hline$p^{*}$ & 0.47 & 0.61 & 0.83 & 0.98 & 0.48 & 0.42 & 0.88 & 0.56 & 0.59 \\
\hline
\end{tabular}

BDL, below detection limit.

${ }^{a}$ Samples collected prior to treatment implementation.

${ }^{b}$ Soil from bay 138 was not analyzed for these parameters.

$* p>0.05$ is not statistically different. 
Table 3. Prerestoration chemical characteristics of surface soil horizon in restored and reference Carolina bays. ${ }^{a}$

\begin{tabular}{|c|c|c|c|c|c|c|c|}
\hline Treatment & $p H(1: 1)$ & $E C(d S / m)$ & $C E C(\mathrm{cmol} / \mathrm{kg})$ & Acidity (cmol/kg) & $T E B(\mathrm{cmol} / \mathrm{kg})$ & Carbon $(\mathrm{g} / \mathrm{kg})$ & Nitrogen $(\mathrm{g} / \mathrm{kg})$ \\
\hline \multicolumn{8}{|l|}{ Restored } \\
\hline$n$ & 16 & 16 & 16 & 16 & 16 & 11 & 11 \\
\hline Maximum & 4.83 & 0.33 & 9.4 & 8.8 & 23.0 & 90.6 & 7.7 \\
\hline Average & 4.27 & 0.08 & 7.2 & 6.6 & 8.6 & 41.1 & 3.5 \\
\hline $\mathrm{SD}$ & 0.24 & 0.09 & 1.4 & 1.3 & 4.7 & 21.7 & 2.1 \\
\hline Minimum & 4.11 & 0.04 & 3.6 & 3.2 & 5.0 & 30.0 & 2.1 \\
\hline Maximum & 4.82 & 0.21 & 8.9 & 8.4 & 20.0 & 37.5 & 3.7 \\
\hline Average & 4.34 & 0.06 & 6.9 & 6.2 & 9.4 & 34.0 & 2.8 \\
\hline SD & 0.25 & 0.07 & 2.20 & 1.97 & 6.22 & 0.35 & 0.06 \\
\hline$p^{*}$ & 0.61 & 0.78 & 0.82 & 0.73 & 0.81 & 0.31 & 0.40 \\
\hline
\end{tabular}

${ }^{a}$ Samples collected prior to treatment implementation.

$* p>0.05$ is not statistically different.

prerestoration reference bays exhibited a hydroperiod gradient from dry (0.01) to primarily wet (0.64). After restoration, the hydrologic response to the treatments was initially complicated by a prolonged regional drought. For the 3-year period 2000-2002, average monthly rainfall fell below the 50-year precipitation average at SRS (Fig.2). However, a positive change in annual hydroperiod (percent time ponded per year) was detected in most $(81 \%)$ of the restored bays during that drought period (Fig. 3a). In 2003, above-normal rainfall patterns were observed at SRS, and all bays except reference bay 57 responded with long duration hydroperiods (Table 4). Normal precipitation levels followed in 2004 and 2005.
Mean hydroperiod for the postrestoration period (20012005) was greater than that of the prerestoration period for all restored and reference bays (Fig. 3b). The mean hydroperiod change for the restored bays, however, was twice as high as that observed for the references ( 0.38 vs. $0.19)$. All restored bays except 124 exhibited an increased hydroperiod change over that of the mean reference.

\section{Influence of Soil on Hydroperiod}

Stepwise multiple linear regression analyses were employed to determine relationships between prerestoration hydroperiod and surface soil characteristics (Tables $2 \& 3$ )

Table 4. Six-year hydroperiod data for restored and reference bays and average postrestoration hydroperiod. ${ }^{a}$

\begin{tabular}{|c|c|c|c|c|c|c|c|c|c|c|c|c|c|c|c|c|}
\hline & \multicolumn{16}{|c|}{ Restored Bays } \\
\hline & 5 & 124 & 126 & 131 & 171 & 5001 & 5011 & 5016 & 5071 & 5092 & 5128 & 5135 & 5184 & 5190 & 5204 & 5239 \\
\hline 2001 & 0.79 & 0.67 & 0.33 & 0.81 & 0.23 & 0.38 & 0.40 & 0.41 & 0.01 & 0.15 & 0.67 & 0.05 & 0.24 & 0.28 & 0.65 & 0.47 \\
\hline 2002 & 0.81 & 0.44 & 0.04 & 0.51 & 0.15 & 0.09 & 0.02 & 0.29 & 0.02 & 0 & 0.55 & 0.04 & 0.13 & 0.01 & 0.52 & 0.01 \\
\hline 2003 & 1.0 & 0.88 & 0.85 & 1.0 & 0.99 & 0.74 & 0.87 & 1.0 & 0.60 & 0.83 & 1.0 & 0.72 & 0.98 & 0.83 & 1.0 & 0.75 \\
\hline Average (post) & 0.92 & 0.63 & 0.42 & 0.75 & 0.50 & 0.39 & 0.50 & 0.74 & 0.19 & 0.31 & 0.79 & 0.27 & 0.48 & 0.34 & 0.79 & 0.39 \\
\hline
\end{tabular}

\begin{tabular}{|c|c|c|c|c|c|c|}
\hline & \multicolumn{6}{|c|}{ Reference Bays } \\
\hline & 57 & 58 & 108 & 118 & 138 & 5055 \\
\hline 2001 & 0 & 0.04 & 0.10 & 0.49 & 0.54 & 0.26 \\
\hline 2002 & 0 & 0 & 0 & 0 & 0.54 & 0.06 \\
\hline 2003 & 0 & 0.87 & 0.89 & 1.0 & 0.99 & 0.94 \\
\hline Average (post) & 0.15 & 0.40 & 0.31 & 0.67 & 0.76 & 0.42 \\
\hline
\end{tabular}

${ }^{a}$ Hydroperiod $=($ fraction of time ponded per year $)$.

${ }^{b} 2000$ represents prerestoration data; average postrestoration value obtained from data collected 2001-2005. 


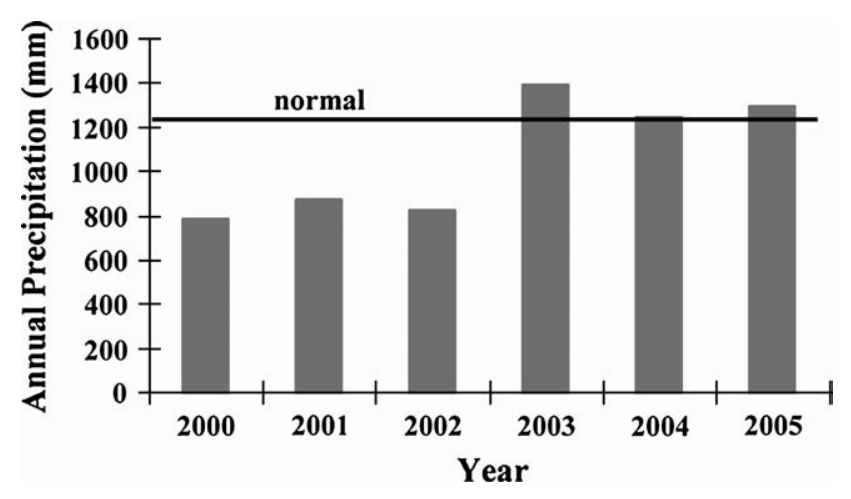

Figure 2. Annual precipitation at the SRS, South Carolina, during the study period. Line for normal rainfall represents the 50-year average from the SRS A-Area weather station.

for all bays (restored and reference). Among the various combinations of variables, it was found that the best single independent soil variable in predicting hydroperiod was EA (Table 5). The best two-variable model was EA and total $\mathrm{N}$, which was significant at the 0.05 level. The best three-variable model was EA, total N, and total C.

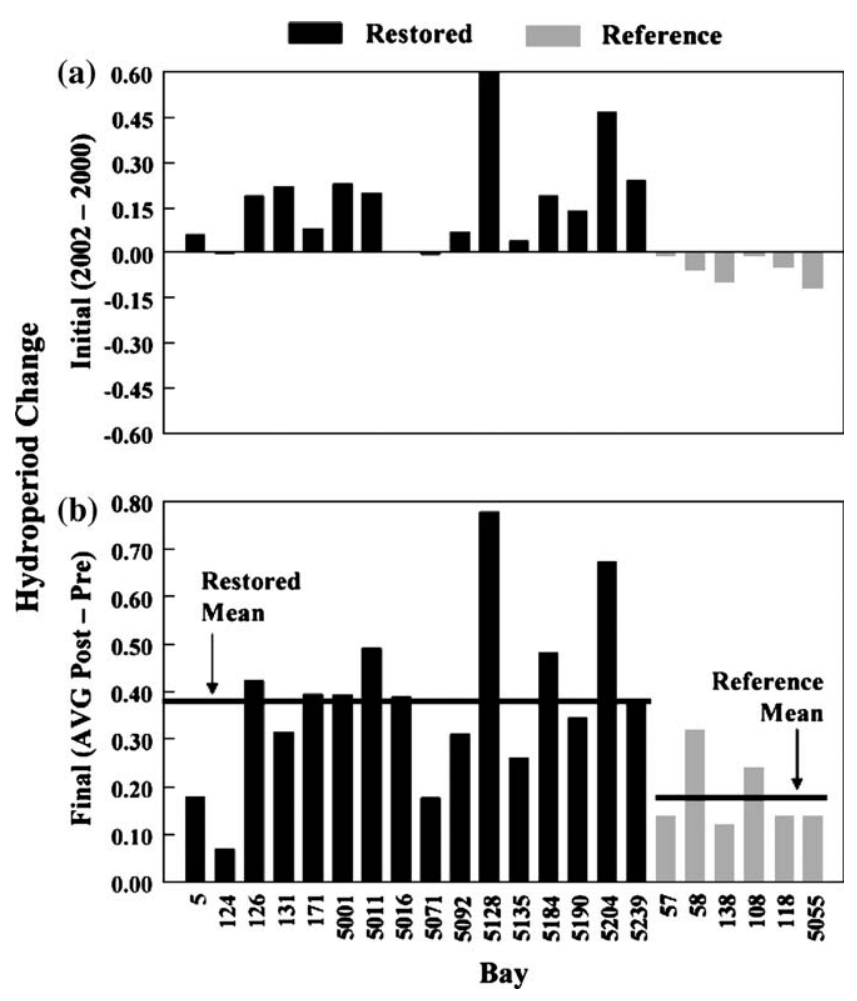

Figure 3. (a) Initial (2000-2002) and (b) final (2000-2005) hydroperiod change from restored and reference bays. Initial hydroperiod change was calculated by subtracting the 2002 hydroperiod from the 2000 prerestoration data. Final hydroperiod change was calculated by subtracting the mean postrestoration hydroperiod (2001-2005) from the 2000 prerestoration data.
Table 5. Multiple linear regression relationships from stepwise analysis between prerestoration bay hydroperiod (Y) and surface soil EA, total nitrogen, and total carbon. ${ }^{a}$

\begin{tabular}{lccc}
\hline Equation & $r^{2}$ Value & F Value & $p>F$ \\
\hline $\mathrm{Y}=0.96-0.08 \mathrm{EA}^{b}$ & 0.36 & 2.38 & 0.12 \\
$\mathrm{Y}=1.41-0.19 \mathrm{EA}^{b}+0.76 \mathrm{~N}$ & 0.51 & 4.13 & 0.05 \\
$\mathrm{Y}=1.24-0.15 \mathrm{EA}-0.06 \mathrm{C}^{b}+1.18 \mathrm{~N}$ & 0.69 & 3.17 & 0.10 \\
\hline
\end{tabular}

${ }^{a} n=15 ; 11$ treatment bays and 4 control bays.

${ }^{b} \mathrm{EA}(\mathrm{cmol} / \mathrm{kg}) ; \mathrm{N}$, total nitrogen (\%); C, total carbon (\%).

Linear regression analyses were also employed to determine relationships between average hydroperiod and soil properties within the entire soil profile of the reference bays. A moderate relationship $\left(r^{2}=0.50, p=0.11\right)$ was observed for the six reference bays (Fig. 4a). Upon further analyses, a stronger correlation was discovered between the hydroperiod and the clay content in the Bt horizon $\left(r^{2}=0.76, p=0.01\right)$, where hydroperiod $=0.0246$ (percent clay content in Bt horizon) - 0.4124 (Fig. 4b). Prerestoration hydroperiod and percent clay in the Bt horizon data for the restored bays were plotted to evaluate the hydrologic status of these sites as compared to that of the reference. The model showed four bays (gray circles: bays $5190,124,131$, and 5016) that were wetter than would be predicted by the regression from the reference bays while

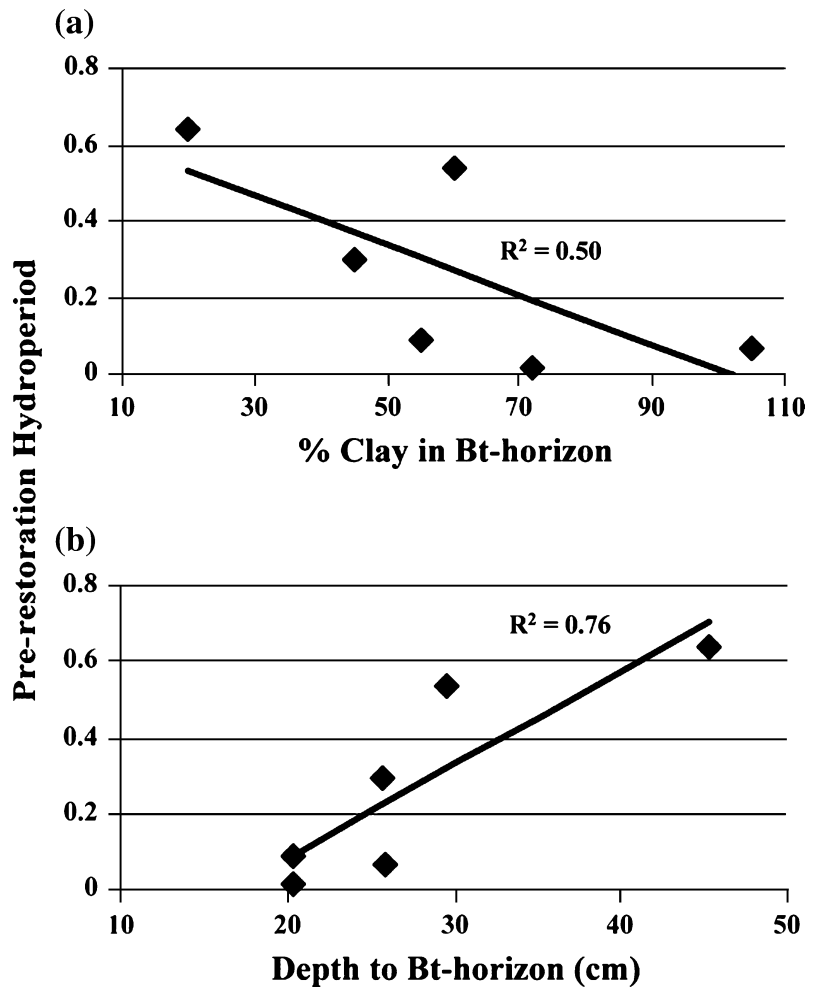

Figure 4. Relationship between hydroperiod and (a) depth to Bt horizon and (b) percent clay content in the Bt horizon in six unrestored reference Carolina bays on the SRS, South Carolina. 
the remaining 12 were at the predicted level or drier (Fig. 5a). This analysis suggests that the hydrologic alteration in the four "wet" bays may not be of sufficient detriment to warrant restoration if the restoration goal is to have a hydroperiod that is similar or greater than that of the reference bays. However, the remaining 12 bays were drier than that observed in the reference bays, and some benefit may be gained through hydrologic restoration.

The mean hydroperiod after restoration was plotted against percent clay in the $\mathrm{Bt}$ horizon to examine how the bays responded to the hydrologic restoration treatment. After restoration, the four wet bays (gray circles) remained on the higher side of the postrestoration reference regression line, indicating that hydrologic response was low (Fig. 5b) and further suggesting that these systems may not have been suitable for restoration. The model also identified bays (diamonds: 5, 126, 171, 5001, 5011, 5128, and 5204) that exhibited an increased hydroperiod after restoration and deviated to or above the regression line between hydroperiod and clay content in the Bt horizon in the reference bays, which suggests a positive resto-

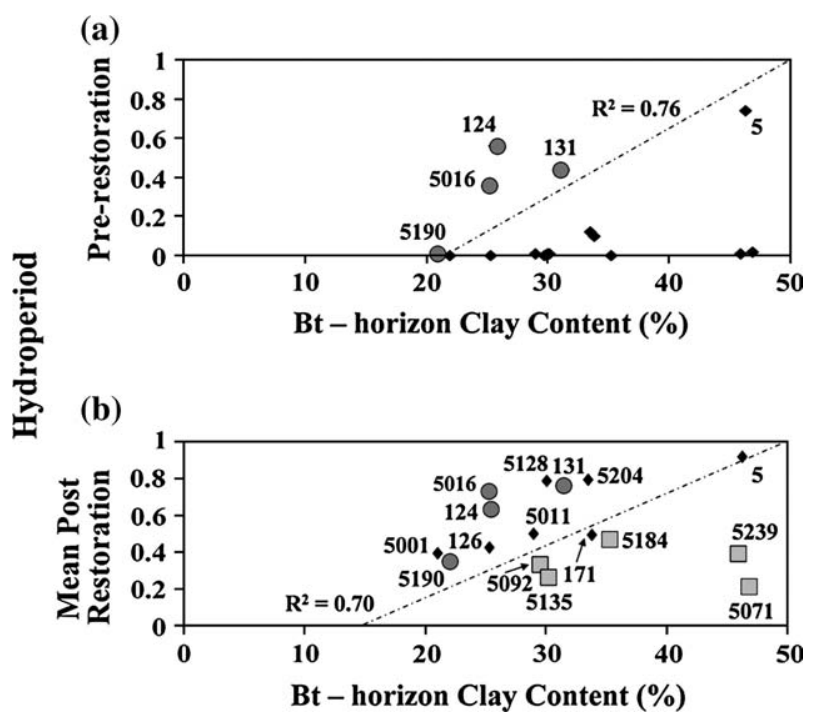

Figure 5. (a) Evaluation of percent clay content in the Bt horizon versus hydroperiod in prerestoration treatment (drained) Carolina bays. The straight line is the line of best fit for the relationship developed for reference bays, where hydroperiod $=0.0246$ (percent clay content in Bt horizon) - 0.4124. Points below the line (diamonds) were drier than predicted by the reference relationship and those above (circles) were wetter. (b) Evaluation of clay content in the Bt horizon versus hydroperiod change in postrestoration Carolina bays as compared to the postrestoration relationship developed for control bays, where hydroperiod $=0.0206$ (percent clay content in Bt horizon) -0.1135 . Diamonds represent those bays that exhibited an increased hydroperiod after restoration and showed a similar relationship between clay content and hydroperiod to that of the control. The squares represent bays that exhibited an increase in hydroperiod after restoration but were drier than would be predicted using control data. The circles indicate sites that were wetter than the reference prior to restoration. ration response. The squares represent bays that exhibited an increase in hydroperiod after restoration but were drier than would be predicted using reference data. Two bays (5071 and 5239) were substantially lower than the reference regression line, suggesting the hydrologic restoration treatments failed or that significant leakage occurred at those sites.

\section{Discussion}

\section{Prerestoration}

Our results indicated that prerestoration soils in the restored and reference bays were not significantly different for all variables examined. This was somewhat surprising given that the restored bays contained active drainage ditches that were well over 50 years in age. We anticipated that the resulting drier conditions would have influenced redox-sensitive soil variables; however, the natural variability in hydrology of these systems was wide enough to include both very dry and permanently ponded bays, as was exhibited by the reference bays 57 and 138. In addition, some restored bays (bays 5, 124, 131, and 5016) may not have had a very effective drainage system prior to restoration due to natural soil sloughing and accretion. Although natural variability in hydrology was high among the bays examined, high standard deviations observed for the soil parameters suggest that a gradient of hydrologic disturbance may have also existed.

Given the wide variation in prerestoration hydroperiod, multiple linear regression analyses were performed to determine what influence, if any, soils had on hydrology in these systems. Our model examined surface soil characteristics because the effects of varying wetness distributions between the sites are likely to be most expressed at the surface layer. In addition, development of a quick method to evaluate hydrologic conditions without a long-term monitoring commitment would be beneficial for assessing hydrologic disturbance in Carolina bays and similar depression wetlands. Among the various combinations of parameters, it was found that the best soil variables for predicting hydroperiod were EA, total N, and total C. All three of these parameters may have been directly or indirectly impacted by changes in soil moisture via draining. A reduction in the hydroperiod could lead to warmer soil temperatures, lower organic matter accumulation (Bolstad \& Vose 2005), higher redox potential $\left(\mathrm{E}_{\mathrm{H}}\right)$, and lower pH (Lindsay 1979), which would result in increased EA. As such, a gradient of these redox-sensitive soil parameters associated with the relative effectiveness of the drainage structure and hydroperiod would be expected.

\section{Postrestoration}

Periodic droughts are a natural but unpredictable occurrence in the southeastern United States that present 
significant restoration challenges (De Steven et al. 2006). Despite the occurrence of a prolonged drought during the early stages of the project, increased hydroperiods in response to restoration activities were observed. In addition to plugging the drainage ditches, hydrologic response was influenced by tree removal and lower water demand in the restored bays via reductions in transpiration. Physical compaction of soils from log skidding may also have contributed to ponding by decreasing infiltration rates. Similar findings pertaining to the role of forest harvesting on wetland hydrology have been noted elsewhere (Sun et al. 2000). One study indicated that the water table rise associated with harvesting is most expressed during periods when the water tables were low (Riekerk 1989), which was the case in this study. The reference bays responded to the drought conditions with hydroperiods that were lower than those exhibited before the restoration began. This response was likely due to timing and number of precipitation events. Water levels in the bays were high at the beginning of 2000 due to a wet period at the end of 1999 . A few large precipitation events were recorded in 2001 and 2002, but they occurred during summer months when the reference bays were dry and evapotranspiration was at its highest.

The task of determining the success of a wetland restoration can be a challenging and sometimes contentious process because "success" is not well defined (Kentula 2000). Methods for evaluating restoration success that compare attributes of the restored system to that of a less disturbed reference system are common. How the information from the reference is used for determining success and which attributes best depict functional enhancement is ambiguous (Society of Wetland Scientists 2003). Because hydrology is a key factor driving wetland function, success criteria based on hydrology have been used in many circumstances (Kusler \& Kentula 1989). If the mean change in reference hydroperiod (post - pre) is used as the target point for assessing hydrologic response, then 15 of the 16 hydrologic restorations in this study would be considered "successful." Given that the prerestoration period was only 1 year and that it occurred during a drought, use of hydroperiod change alone for evaluating hydrologic response may be problematic and other metrics should be considered. Chmielewski (1996) and DeSteven and Toner (1997) described a relationship between bay vegetation and depth to clay and suggested that a similar relationship may exist between hydroperiod and depth to clay. Although this relationship was found to be weak in our study sites, a strong correlation between hydroperiod and clay content in the argillic horizon of reference bays was observed. Using this relationship, we were able to evaluate whether a site was suitable for restoration and provide another option for determining restoration success. Four sites were identified in the analysis that were initially too wet and likely would not benefit from hydrologic restoration. Confirmation of a small hydroperiod change in these four sites after restoration was recognized by the method, which further suggests that their drainage ditches were not fully functioning prior to restoration. Seven restored bays were shown to exhibit significant increases in hydroperiod by this method while the remaining five sites showed limited response as compared to the reference.

There is a growing concern that wetland restoration projects do not consistently replace lost wetland structure and function (Zedler \& Callaway 1999; Kentula 2000; Streever 2000; Kolka et al. 2002). Our results showed that this issue can be complicated even further by the methods employed for evaluating restoration response. Clearly, the two methods we used yielded differing results. Although hydroperiod change is commonly used for evaluating hydrologic response to restoration, use of this information in ephemeral wetlands such as Carolina bays may be misleading unless you have long periods of data before and after restoration. Soil characteristics are less likely to exhibit wide fluctuation in response to periodic wet and dry periods than surface hydrology. As demonstrated in this study, integration of soil parameters into models for evaluating isolated depression wetland hydroperiod may better reflect long-term saturation conditions. Use of this approach could provide restoration practitioners a method for enhancing prerestoration hydrology monitoring and an alternative to traditional methods for evaluating restoration success in Carolina bays and other isolated depression wetlands.

\section{Conclusions}

This study revealed that select soil physicochemical properties could be used to predict Carolina bay hydroperiod and to evaluate the suitability of a bay for hydrologic restoration. Multiple linear regression analyses revealed that the chemical properties of bay surface soil samples were influenced by the variability in hydrology that these sites exhibit. Parameters that are sensitive to soil redox change or flooding, such as EA, total N, and C, were found to be good indicators of hydroperiod in our sites. As such, an evaluation of hydrologic disturbance may be performed without the long-term cost of monitoring. Regression analysis of physical parameters from the entire soil profile also revealed a significant relationship between hydroperiod and clay content in the Bt horizon. The relationship was used to predict hydrologic response using prerestoration hydroperiod data. The model accurately identified sites that did not need hydrologic restoration (too wet). Subsequently, the model was employed to examine postrestoration hydroperiod, and it effectively showed sites that appeared to respond well to the restoration activities. The number of disturbed Carolina bays in the southeastern United States could be in the tens of thousands (Sharitz 2003), given these conditions, soil physicochemical characterizations, appear to be an important and costefficient step in assessment procedures used to determine restoration suitability. 


\section{Implications for Practice}

- Testing of soils in disturbed depression wetlands for redox-sensitive parameters such as EA, total nitrogen, and total carbon may provide useful information about the long-term moisture status of a site and suitability for restoration. This information may enhance prerestoration hydrology monitoring, especially when the monitoring duration is short.

- The relationship between the hydroperiod (duration of ponding) and the percent clay content in the $\mathrm{Bt}$ horizon of Carolina bay wetlands in the upper coastal plain of the southeastern United States was found to be useful for evaluating response to hydrologic restoration and may complement traditional methods used for evaluating restoration success.

- Hydrologic restoration of disturbed Carolina bay wetlands was achieved by plugging drainage ditches.

\section{Acknowledgments}

This work was funded by the U.S. Department of Energy-Savannah River Operations Office through the U.S. Forest Service-Savannah River (Financial Assistance Award DE-IA09-00SR22188). Additional support was provided by the U.S. Forest Service Center for Forested Wetlands Research and the University of Georgia Savannah River Ecology Laboratory. Special thanks to D. De Steven, R. Sharitz, C. Trettin, J. Singer, J. Blake, S. Czapka, and A. Davis.

\section{LITERATURE CITED}

Barton, C. D., J. I. Blake, and D. W. Imm. 2005. Ecological restoration. Pages $70-83$ in J. C. Kilgo and J. I. Blake, editors. Ecology and management of a forested landscape: fifty years of natural resource stewardship on the Savannah River Site. Allen Press, Washington, D.C.

Barton, C. D., D. D. DeSteven, and J. C. Kilgo. 2004. Mitigation bank promotes research on restoring coastal plain depression wetlands (South Carolina). Ecological Restoration 22:291-292.

Bennett, S. H., and J. B. Nelson. 1991. Distribution and status of Carolina Bays in South Carolina. South Carolina Wildlife and Marine Resources Department, Columbia, South Carolina.

Bolstad, P. V., and J. M. Vose. 2005. Forest and pasture carbon pools and soil respiration in the southern Appalachian Mountains. Forest Science 51:372-383.

Chmielewski, R. M. 1996. Hydrologic analysis of Carolina bay wetlands at the Savannah River Site, SC. M.S. thesis. University of WisconsinMilwaukee, Milwaukee.

De Steven, D., R. R. Sharitz, J. H. Singer, and C. D. Barton. 2006. Testing a passive revegetation approach for restoring coastal plain depression wetlands. Restoration Ecology 14:452-460.

DeSteven, D. D., and M. Toner. 1997. Gradient analysis and classification of Carolina bay vegetation: a framework for bay wetlands conservation and restoration. USDA Forest Service, Savannah River, New Ellenton, South Carolina.

Downing, D., C. Winer, and L. D. Wood. 2003. Navigating through Clean Water Act jurisdiction: a legal review. Wetlands 23:475-493.
Environmental Laboratory. 1987. Corps of Engineers wetlands delineation manual. Technical Report Y-87-1. U.S. Army Engineer Waterways Experiment Station, Vicksburg, Mississippi.

Federal Interagency Committee for Wetland Delineation. 1989. Manual for identifying and delineating jurisdictional wetlands. U.S. Army Corps of Engineers, USEPA, U.S. Fish and Wildlife Service, and USDA-SCS, Washington, D.C.

Kentula, M. E. 2000. Perspectives on setting success criteria for wetland restoration. Ecological Engineering 15:199-209.

Kolka, R. K., C. C. Trettin, E. A. Nelson, C. D. Barton, and D. E. Fletcher. 2002. Application of the EPA Wetland Research Program approach to a floodplain wetland restoration assessment. Journal of Environmental Monitoring and Restoration 1:35-51.

Krajick, K. 1997. The riddle of the Carolina Bays. Smithsonian 28:45-55.

Kusler, J. A., and M. E. Kentula. 1989. Wetland creation and restoration: the status of the science, vol. 2. Perspectives Report 600/3-89/038b. EPA, Washington, D.C.

Lide, R. F., V. G. Meentemeyer, J. E. Pinder III, and L. M. Beatty. 1995. Hydrology of a Carolina bay located on the upper coastal plain of western South Carolina. Wetlands 15:47-57.

Lindsay, W. L. 1979. Chemical equilibria in soils. John Wiley \& Sons, New York.

Mahoney, D. L., M. A. Mort, and B. E. Taylor. 1990. Species richness of calanoid, copepods, cladocerans, and other branchiopods in Carolina bay temporary ponds. American Midland Naturalist 123:244-258.

Natural Resources Conservation Service. 1996. Soil survey laboratory methods manual. Soil survey investigations. Report No. 42. USDA, Washington, D.C.

Newman, M. C., and J. F. Schalles. 1990. The water chemistry of Carolina bays: a regional study. Archive für Hydrobiologie 118:147-168.

Petrie, M., J.-P. Rochon, G. Tori, R. Pederson, and T. Moorman. 2001. The SWANCC decision: implications for wetlands and waterfowl. Ducks Unlimited, Inc., Memphis, Tennessee.

Reese, R. E., and K. K. Moorhead. 1996. Spatial characteristics of soil properties in a Carolina bay wetland. Soil Science Society of America 60:1273-1277.

Riekerk, H. 1989. Influence of silvicultural practices on the hydrology of pine flatwoods in Florida. Water Resources Research 25: 713-719.

Rogers, V. A. 1990. Soil survey of Savannah River Plant area, parts of Aiken, Barnwell, and Allendale Counties, South Carolina. USDA SCS. U.S. Government Printing Office, Washington, D.C.

SAS Institute. 1999. SAS version 8 for Windows. SAS Institute, Inc., Cary, North Carolina.

Schalles, J. F., R. R. Sharitz, J. W. Gibbons, G. J. Leversee, and J. N. Knox. 1989. Carolina Bays of the Savannah River Plant. Page 70. Savannah River Site-National Environmental Research Park Publication 18, Aiken, South Carolina.

Semlitsch, R. D., D. E. Scott, J. H. K. Pechmann, and J. W. Gibbons. 1996. Structure and dynamics of an amphibian community: evidence from a 16-year study of a natural pond. Pages 217-248 in M. L. Cody and J. A. Smallwood, editors. Long-term studies of vertebrate communities. Academic Press, San Diego, California.

Sharitz, R. R. 2003. Carolina bay wetlands: unique habitats of the southeastern United States. Wetlands 23:550-562.

Sharitz, R. R., and J. W. Gibbons. 1982. The ecology of southeastern shrub bogs (pocosins) and Carolina bays: a community profile. Page 93. FWS/OBS-82/04. U.S. Fish and Wildlife Service, Division of Biological Services, Washington, D.C.

Society of Wetland Scientists. 2003. Performance standards for wetland restoration and creation. SWS Position Paper. (available from http:// www.sws.org/wetland_concerns/performance.mgi) accessed 15 June 2008 .

Sparks, D. L., A. L. Page, P. A. Helmke, R. H. Loeppert, P. N. Soltanpour, M. A. Tabatabai, C. T. Johnson, and M. N. Sumner. 1996. Methods 
of soil analysis, chemical methods. Soil Science Society of America Publications, Milwaukee, Wisconsin.

Streever, W. J. 2000. Spartina alterniflora marshes on dredged material: a critical review of the ongoing debate over success. Wetlands Ecology and Management 8:295-316.
Sun, G., H. Reikerk, and V. Kornhak. 2000. Ground-water table rise after forest harvesting on cypress-pine flatwoods in Florida. Wetlands 20: 101-120.

Zedler, J. B., and J. C. Callaway. 1999. Tracking wetland restoration: do mitigation sites follow desired trajectories? Restoration Ecology 7:69-73. 